\title{
Detecting Land Use Change in The Jordan University District During the Period of (1985-2019) Using GIS and Remote Sensing
}

\author{
Lina Ahmad Ali Bany Salameh* \\ Researcher \\ Amman-Jordan \\ Email: Lena97045@Gmail.Com / Lina.Slameh3@Gmail.Com \\ Jordan \\ Associated Prof. OMAR Farhan Al-Sagarat \\ Department of Geography \\ Mutah University \\ Karak-Jordan \\ Email: Sagarat@Mutah.Edu.Jo \\ Jordan
}

\section{ABSTRACT}

This study aimed to evaluate the changes in usage patterns of lands in Jordan University district for the period (1985-2019), demonstrate the impact of natural factors, humans, in the use of change, and identify the trend of urbanization. To achieve the study objectives, the analytical method, descriptive method, and historical method were used, it also relied on Landsat satellite images, images by Google Earth Pro, and metadata serving the subject of study.

The study findings demonstrated the changing in the land use due to increasing urban lands by $12.5 \%$ during the study period, decreasing agricultural lands by $-40 \%$, decreasing rangeland by $-49 \%$, decreasing barren lands by $-42.6 \%$, and decreasing forest area by $-50.5 \%$. The study used logistic regression, to predict the usage area of urban and agriculture aspects, and it is demonstrated increasing the urban land by (110823donums) of the district's area, and decreasing the agriculture lands by 2029.

\section{Keywords: Jordan University District, Land Use Classification, GIS Techniques, Urban Growth, Land_Use Change.}

\section{Introduction}

University is the most significant urban area in Amman, which is characterized by densely populated approximately (6801.18 people/ km2) (Department of Statistics, 2019), also characterized by the high level of qualification and culture. It has become a center for academic institutions, as the University of Jordan, Applied Science Private University, Princess Sumaya University for Technology, Faculty of Amman College, Royal Jordanian Geographic Centre, and many academic private collages were established there. Furthermore, the distinction of the university district by a natural environment with rich soil, temperate climates, and undulating topography, as the hills and low-level plateaus has dropped off in its topography, which has made the district a center of the attention for the people, in particular, the investors to implement their urban and economic projects.

The researchers have been tended to use the techniques of remote sensing and GIS to planning and organizing the cities, as these techniques may assist in terms of analyzing and interpreting the various data, in addition, to facilitate the tasks of developers in terms of research and creating a spatial database and tracking different phenomena (Ramachandran et al., 1997؛ Matsa et al., 2020؛Schaefer \& Thinh, 2019). With the need to understanding and considering Man's need for the earth and its resources, and the emergence of description for the various using of lands, the researchers seek to research in the scope of patterns of change and development in land use. The study of Alawran (2019) discussed the changes in land use at Alieas town/ Tafilah Governorate during the period of (1980-2015) by using remote sensing and GIS techniques. In addition to what was contained in the Alta'ani study (2007) by research in the development of land use over a specific period at Bani Kenanah district.

This study considers the land uses the change in the university district from 1985 to 2019 , in addition, to clarify the human and natural causes that led to that change, by providing the interpretation of satellite imagery and aerial photographs to the area during the period of the study, and support them by metadata that collected from various sources. The researchers have presented a prediction for the reality of urban and agricultural uses during the ten years following the study period, using the Logistic Regression method.

The study significance has been highlighted by identifying the lands' using, its stages of development as an essential part of organizing, planning, and optimizing cities, and achieve the optimal using, as the area in 1985 was included an area of agricultural and pastoral land exceeding $76.6 \mathrm{Km} 2$, but it decreased until it reached $42.1 \mathrm{~km}^{2}$ in 2019 (analysis of satellite imagery, 1985-2019), it has also decreased in the face of natural population growth in conjunction with waves of Iraqi and Syrian human asylum in exceptional 


\author{
E-ISSN: 2469-6501 \\ VOL: 7, ISSUE: 9 \\ September/2021 \\ DOI: http://dx.doi.org/10.33642/ijbass.v7n9p1 \\ (c) $\stackrel{0}{\mathrm{E}}$ \\ https://creativecommons.org/licenses/by/4.0/
}

circumstances in which the number of non-Jordanian arrivals to the district in 2015 reached (339202 people) and they constitute $46 \%$ of the district's population, that leads to increase the wages from $3.55 \%$ in 2012 up to $6.76 \%$ in 2014, which resulted in changes to the user of the lands and change in the trend of urban growth (population statistics, 2019).

\section{Methodology of the Study}

Study Area

\section{University District-Amman}

The university district is located in the north-western part of Amman, between the latitude of ( $\left.31^{\prime} 57^{\prime \prime} 14.83^{\circ}\right)$ and $\left(32^{\prime} 5^{\prime \prime} 5.84^{\circ}\right)$ north, and between meridian (35'47 "51.47 $)$ \& $\left(36^{\prime} 00{ }^{\prime \prime} 22.94^{\circ}\right)$ east, and the district has an area 120.94079 $\mathrm{km} 2$ and administratively affiliated to the Amman governorate, according to administrative divisions rule issued by Ministry of Interior No. 31 of 1995, according to Article (120) from the constitution. As the resolution of joining the district to capital governorate has ratified on 01/01/1996. And has this name after the University of Jordan, as it is the first academic institution established in Jordan in 1962, where Jubaiha area was selected (One of the district's five areas) the perfect place to establish the university. The district consists of five administrative areas affiliated to the Greater Amman Municipality (Jubaiha, Tala Alali, and Khalda and Um Alsummaq, Sweileh, Abo Nsir, and Shafa Badran). And the levels range of highlands and eastern plateaus for the Balqa Mountains in the study area (1080m in Sweileh \& 700m in Shafa Badran).

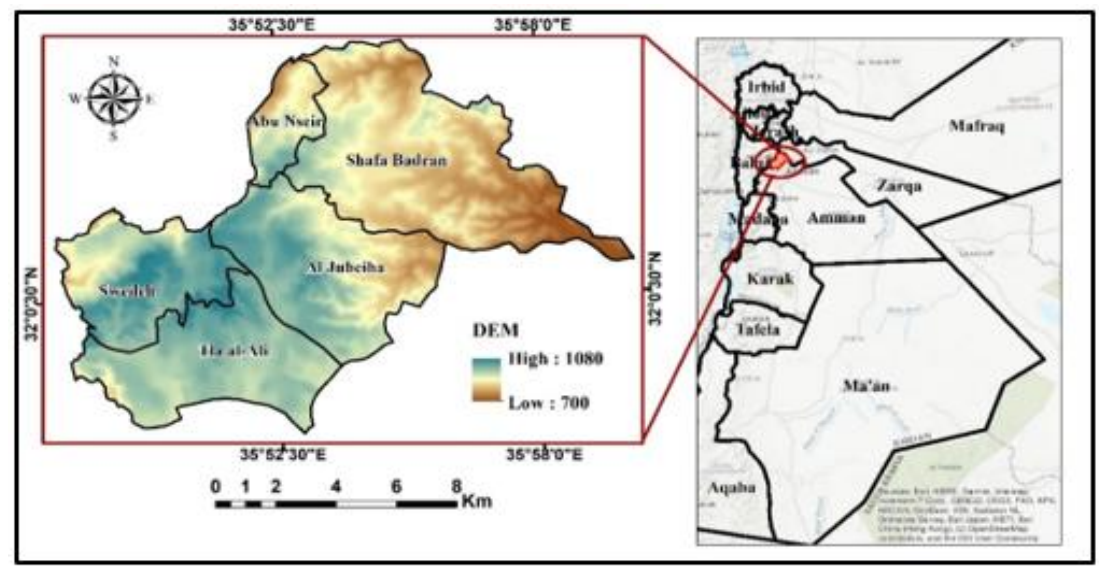

Fig.1: Location Of The Jordan University District

The Levels Of Study Area Ranged Between 1080m In Mediterranean Soils and Shallow as Well as Inception Soils Sweileh \& 700m In Shafa Badran, As For The Rainfall, Vary Limestone and Typical Ones Have Prevailed in University In Spatial Distribution And Volumes In Line With Spatial District. It Was Formed by The Factors of Weathering and Variation Of Urographic Factor; By Tracking The Amount Of Erosion, And The Drifting It Was Exposed to by Wind and Rainfall In Jubaiha And Sweileh In The Period 199-2019, We Rain, And Most of It Is Derived from Limestone and Found That The Highest Amount Of Rainfall Ranged 1004mm Calcilutites, As Shown in The Soil Map, Figure (2) The For The Season (1991/1992) In Jubaiha, 950.6mm In Sweileh Largest Part of The Study Area Consists Of Fertile Soil Due In The Same Season, Where The Lowest Amount Of Rainfall To Its High Content Of Clay And Oxides And Its High Ability Was 226.5mm In Sweileh In Season (1994/1995), And To Exchange Ions, And It Is Suitable For Field Crops 295.1mm In Jubaiha. The Geographical Distribution of Soils in According To The Soil Classification Of The Ministry Of University District Reflects Environmental Conditions of Agriculture (Lagarde And Bouhali 2013; Matouq Et Al. 2013) Climate, Topography and Rock Structures; As The Ripping

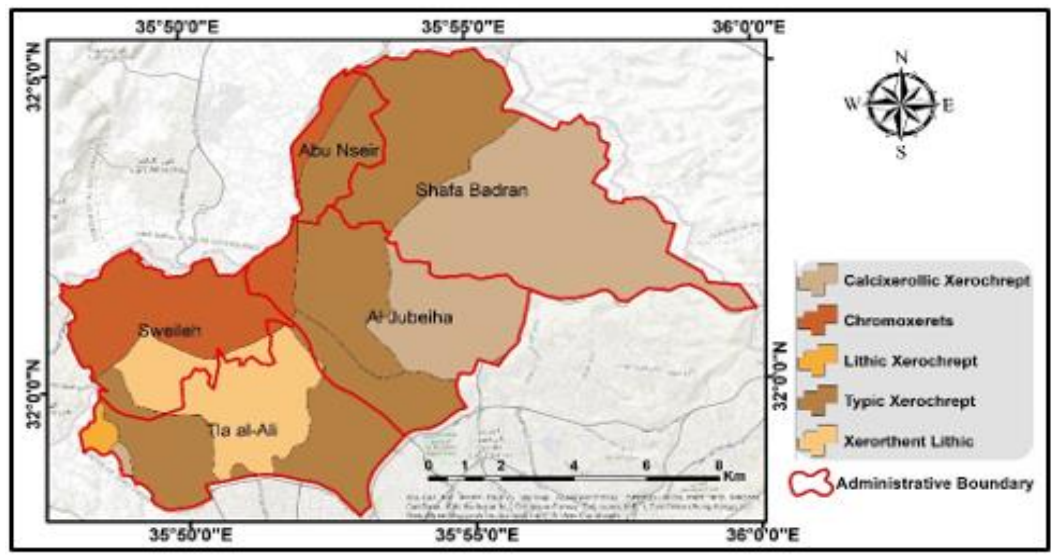

Fig. 2: Soil Map of the Jordan University District 2012. 


\title{
International Journal of Business and Applied Social Science (IJBASS)
}

\author{
E-ISSN: 2469-6501 \\ VOL: 7, ISSUE: 9 \\ September/2021 \\ DOI: http://dx.doi.org/10.33642/ijbass.v7n9p1

\subsection{Data acquisitions}

- Metadata: Includes Books, Periodicals, Research Papers Obtained from Paperwork, And Records Obtained from Public Departments and Ministries; That Contained the Numbers of Jordanian and Non-Jordanian Residents for Different Periods of the Study Area, Rainfall Amount for The Period of the Study (1985-2019) Form Ministry of Water \& Irrigation, And Data from Weather Stations.

- Geodata: Includes All Satellite Images from
Survey (USGS) As Shown in The Table (1), And Aerial Photos That Obtained by Using " Google Earth Pro" Application, Which Contained an Archive of Aerial Photos "Image History", And It Was Used the Aerial Photos for The Years $(1985,1990,1995,2000,2005,2010,2015,2019)$ In Resolution 6m. The Geodata Includes Also the Soil Map of 2012, And Map of Administrative Divisions for The Study Area of 2009 Obtained from Relative Pubic Departments.

Lanasat, Which Obtained from United States Geological

Table 1 Characteristics of Data Collected

\begin{tabular}{lcc}
\hline Sensor & Day/Month/Year & Resolution \\
\hline Landsat_5 ETM + & $24 / 05 / 1985 ، 15 / 03 / 1990 ، 29 / 03 / 1995$ & $30 \mathrm{~m}$ \\
& $27 / 05 / 2005,10 / 06 / 2010$ & \\
Landsat_7 ETM + & $21 / 05 / 2000$ & $30 \mathrm{~m}$ \\
Landsat_8 OLI & $05 / 04 / 2015,03 / 06 / 2019$ & $30 \mathrm{~m}$ \\
\hline \multicolumn{2}{c}{ Source: (Http://Glovis.Usgs.Gov) }
\end{tabular}

\subsection{Image Pre-Processing}

The Techniques of Remote Sensing Were Used in This Study Essentially, Through The Software " ERDAS Imagine 2014", And Techniques of GIS Through the Software "Arcgis" And Application Arcgis Online, To Process the Aerial Photos Obtained from Its Initial Sources to Get Accurate Information That Will Assist to Solve the Study Problem, Answer Its Questions, And Achieve Its Objectives. In Addition to Use Software "Excel" To Conduct the Statistical Analysis and Review the Results in the Form of Tables and Graphs.

Image Processing Using Remote Sensing Technique, By Erdas Imagine Software 2014. Through The Following Steps:

- Image Enhancement: The Processing of Image Enhancement Was Applied on The Images in This Study Using Histogram Equalization; Which Is a Processing of Reallocate the Values of Pixel to Entire Scale of Histogram Equalization by Setting the Lowest Value at Zero and Higher at 255. The Technique of Edge Enhancement Also Applied; Which Help to Reduce the Intensity Contrast in The Colors of the Image's Edges, To Increase Clarity in The Process of Visual Interpretation of the Visual Space. (Schaefer and Thinh 2019)

- Resolution Merge: This Process Aims to Merge the Best Spatial Resolution with The Best Spectral Bands, As the Satellite Visual Takes the Spatial Resolution of the Aerial Image Without Compromising the Spectral Resolution. In This Study, Aerial Photos with A Resolution of 6 Meters Were Used, To Do the Merging Process; So That Every Aerial Image Was Merged with The Satellite Visual for The Same Year.

- Image Interpretation: They Are the Processes of Identifying, Describing, and Evaluating Phenomena on The Earth's Surface. The Classification Is Based on Two Types, Which Are: Supervised Classification \& Unsupervised
Classification. The Main Difference Between Them Is That the Directed Classification Is Based on Real Information About Geographical Phenomena Given to The Computer. While The Non-Directed Classification Is Done According to Mathematical Equations That Define the Classification Classes According to The Relationship Between the Numerical Values of the Image Ranges (Alsaleh, 2010). In The Study, A Supervised Classification of Satellite Images Was Performed, Then Assessment of Classification Accuracy Was Done On the Classified Images by Kappa Index and Confusion Matrix (Keshtkar Et Al., 2017; Esmail Et Al., 2016) To Test the Images Resolution and Compare Them to The Actual Points, Using Random Points and Projecting Them to Aerial Images Taken from Google Earth Pro. For Each Stage of the Study, Then Five Classifications Were Used for The Area as Follows: (Anderson, 1971; James R. Anderson, 1976))

1. Urban Land: It Includes the Residential and Commercial Complexes and Services of All Kinds, Transportation and Communication Networks, Utilities, Industrial and Commercial Complexes, And Overlapping Lands in Urban or Built Areas.

2. Agricultural Land: It Includes Fertile Agricultural Lands with A Suitable Environment and Climate for Agriculture. The Study Included Cultivated and Unmanaged Lands.

3. Rangeland: It Included Grassy Rangelands, Shrubs, Rainfed and Irrigated Mixed Pastures, And Gardens Identified Through Aerial Photos.

4. Barren Land: It Includes Lands with Exposed Rocks Devoid of Vegetation, Which Were Often Formed Due to Construction, Excavation Operations for Road Construction, And Housing and Commercial Projects in The Area.

5. Forest Land: Evergreen Forests, In The Study Area, Were More Representative of the Lands That Contain 


\author{
E-ISSN: 2469-6501 \\ VOL: 7, ISSUE: 9 \\ September/2021 \\ DOI: http://dx.doi.org/10.33642/ijbass.v7n9p1 \\ (c) (†) \\ https://creativecommons.org/licenses/by/4.0/
}

Forest Trees, Which Were Distinguished Through the Field Visit and Aerial Photos, And They Are the Forest Lands of the Ministry of Agriculture.

Process and Analyze Data Using ArcGIS Pro Geographic Information Systems

ArcGIS Pro Version Was Used to Build a Geographical Database with The World Geodetic System (WGS84) For The Study Area, Which Includes Maps of Land Use Resulting from The ERDAS Application and The Two Administrative Divisions Maps and Roads for The District. At This Stage, The Maps Were Linked to The Metadata from The Evolution of Population Numbers, A Description of Each Type and Its Area Calculation; This Is to Create a Complete Perception of the Change in Land Use for Each of the District's Areas, Then Layout It in Its Final Form. Consequently, A Time Series of Land Use Maps Was Formed, Showing The Area and Distribution of Each Use in The Study Area.

Share the Geographical Database Using ArcGIS Online.

To Share Maps, Layers, And Project Packages to ArcGIS Online and Convert Them into A Web Application, An Account On ArcGIS Online Was Created, Then Upload the Maps to Publish to A Web Map.

Using Excel to Predict the Area of Agricultural and Urban Land

Predicting The Area of Urban and Agricultural Lands for Ten Years Following the Study Period (2020-2029): This Was Done Through Two Stages, first: Using The Equation to Predict Future Values of the Population (Henry S. Shryock, 1976; Namboodiri Et Al., 1973):

$\mathrm{P} 2=(\mathrm{P} 1 * \mathrm{E} * \mathrm{R} * \mathrm{~T})+\mathrm{P} 1$

Where: $\mathrm{P} 2=$ Expected Population, $\mathrm{P} 1=$ Population in The Base Year (The Population Was Used for The Last Census in 2019), E Is a Fixed Amount= 2.718, R= Population Growth Rate (The Population Growth Rate Between 2015-2019 Of 2.5\% Has Been Used, Assuming That the Region Is Stable from Forced Migrations and That No Exceptional Cause Will Occur in The Future), And $\mathrm{T}=$ period Between Each Census and The Next.
Second: Use The Logistic Regression Method; It Was Applied On Excel Program, Is A Statistical Model Affiliated to Logistic Regression Models and Used to Analyze the Effect of a Quantitative Variable On Another Quantitative Variable to Predict a Particular Phenomenon (Luo Et Al., 2008; Cao Et Al., 2020; Park Et Al., 2011)

\section{Results}

Using The Mathematical Equation: (Rate of Change $=\{($ Present Value/Previous Value $)-1\} \times 100)($ Bennett and Humphry 1995) The Change Was Calculated for Each Type of Land Use in The District, and by Dividing the Main Study Stage into Periods of Five Years Between the Period to The Next One, As A Following:

-The Reality of Land Use for The University's District for The Year 1985 (The Beginning of the Study Period).

The Results Of The Analysis Of The Reality Land Use Map In The University District For The Year 1985 Showed Figure (3), The Area Of Agricultural Land Amounted To (46039.36 Dunums), At 38\% Of The Total Area Of The District, Which Amounted To (120,940.07 Dunums), Followed By Rangeland, Which Occupies An Area Of (33486.33 Dunums) Of The Area Of The District Amounting To $\left(120.94079 \mathrm{Km}^{2}\right)$ At A Rate Of $28 \%$, While The Urban Lands It Occupied An Area (31,707.05 Dunams), Or 26\% Of The Area Of The District, This Is Followed By Bare Lands And Forests, Which Occupied (7021.62 Dunams) 6\% And (2,683.49 Dunams) 2\% For Each, Respectively. This Change Can Be Attributed to The Rapid Population Growth in The Capital Amman, Which Was Represented by The Emergence of Many Popular Markets, Government Establishments, Parks, And Informal Commercial and Residential Projects. The University District Witnessed an Increase and A Change in The Population, So The Population of the District in 1979 Reached 39,702, And Urban Growth Spread Between Tla'a AlAli, Jubaiha, And Sweileh, As More Than $80 \%$ Of The Total Population of the District Settled in These Areas. (Department of Statistics, 1979).

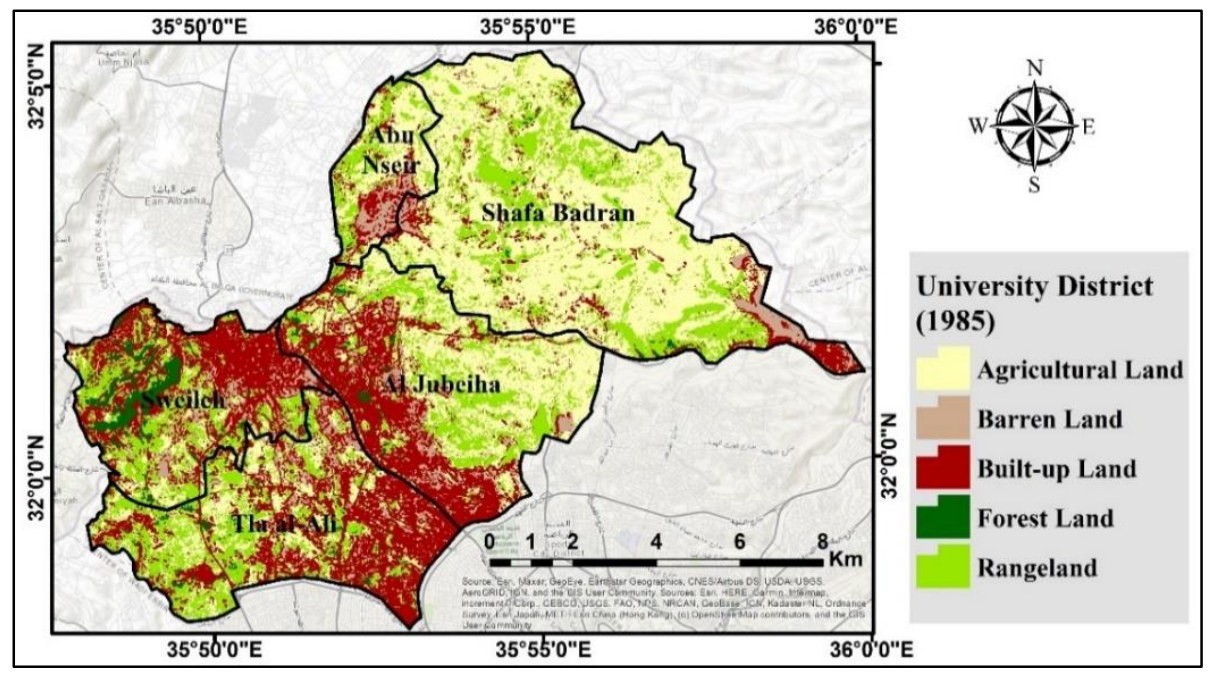

Fig. 3: Map of Land Use in The University District for The Year 1985. 


\author{
E-ISSN: 2469-6501 \\ VOL: 7, ISSUE: 9 \\ September/2021 \\ DOI: http://dx.doi.org/10.33642/ijbass.v7n9p1 \\ (c) (i) \\ https://creativecommons.org/licenses/by/4.0/
}

\section{- Change in Land Use for The University District During the Period Between 1985 And 1990.}

By Calculating the Percentage Change Between 19851990, We Found That the Barren Lands Increased by $27 \%$, Agricultural 21\%, And Urban 7\% Against The Rangeland, Which Decreased By-41\%, Also, The Area of Forests Decreased By $-9 \%$, So The Lands Planted with Forest Trees Have Decreased. Through Figure (4), Which Represents the Land Use in The University District for The Year 1990, It Is Evident That Agricultural Lands Have Crept into Pastoral Lands, So That the Area of Agricultural Lands Constitutes (56,497.459 Dunams), Which Is 47\% Of The Total Area of The District, While The Area of Pastoral Lands Has Decreased. To (19,906,588 Dunams), A Rate of $16 \%$ Of The
Total Area of The Area, And The Percentage of Urban Land Increased from 1985, Reaching (32,599.914 Dunams), Or About 27\%, And The Percentage of Barren Land Also Increased to $(9,490,689$ Dunams), About $8 \%$. This Is Due to The Increase in Housing Projects and The Beginning of the Population's Tendency to Work in Service Projects Instead of Agricultural and Pastoral Projects. The Percentage of Lands Covered by Forests Remained in Preservation of Their Value During This Period (2\%) At (2,446,143 Dunums) Because The Largest Percentage of Forests in The University District Represent the State's Forested Lands and Are Protected by A Law That Prohibits the Sale, Delegate or Allocation of Land (The Forest Land Reclamation Law). For 1971).

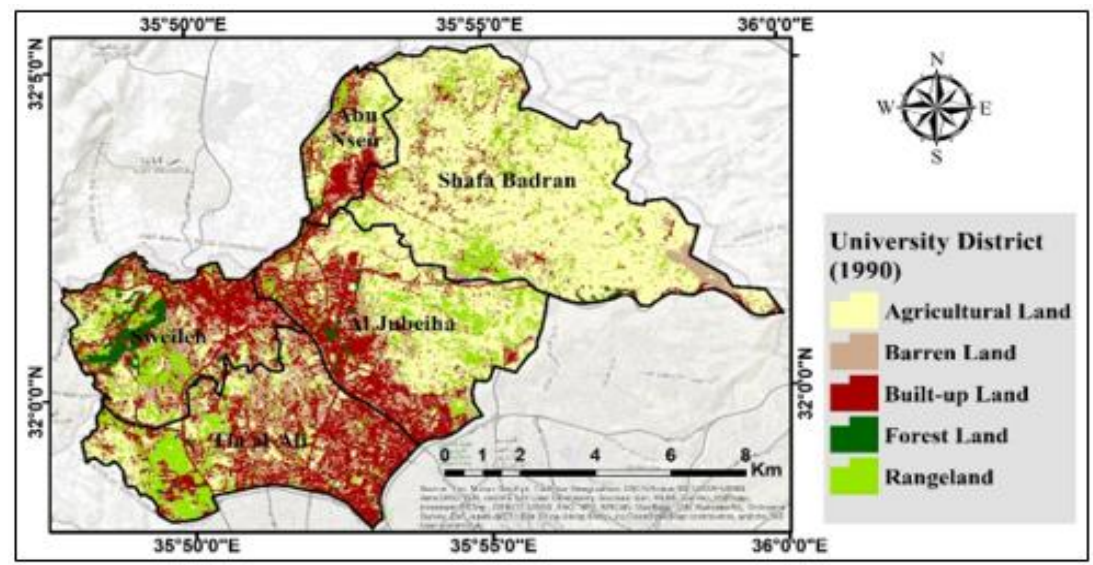

Fig. 4: Map of Land Use in The University District for The Year 1990.

-Change in Land Use for The University District During the Period Between 1990 And 1995.

This Period Was Marked By The Immigration From The State Of Kuwait In 1991, In Addition To The Establishment Of New Scientific Institutions, Including Princess Sumaya University For Technology, Which Was Established In 1991, And The Population Doubled At This Stage Where The Population In The District In 1994 Reached (166780 People), And Based On This Change, The Proportion Of Urban Lands Reached In The Year 1995 To $(37,783,723$ Dunams), Constitutes Of 31\% Of The District's Area, That Is,
An Increase Of 16\%, At The Against The Agricultural Lands, Which Decreased By -9\% For The Period 1990-1995, Forming (51,309,056 Dunams), I.E. 43\% Of The District's Area, As For The Pastoral Lands, They Increased By 5\%, To Occupy (20,885,525 Dunums) By 17\% Of The District's Area, While The Barren Lands Decreased By-7\%, Which Made Up (8,849.135 Dunams) 7\% Of The District's Area, And Forests Decreased By A Slight -1\%, To Become (2,113,522 Dunams), I.E. 2\% Of The District's Total Area. Figure (5) Shows A Map of Land Use in The University District for The Year 1995.

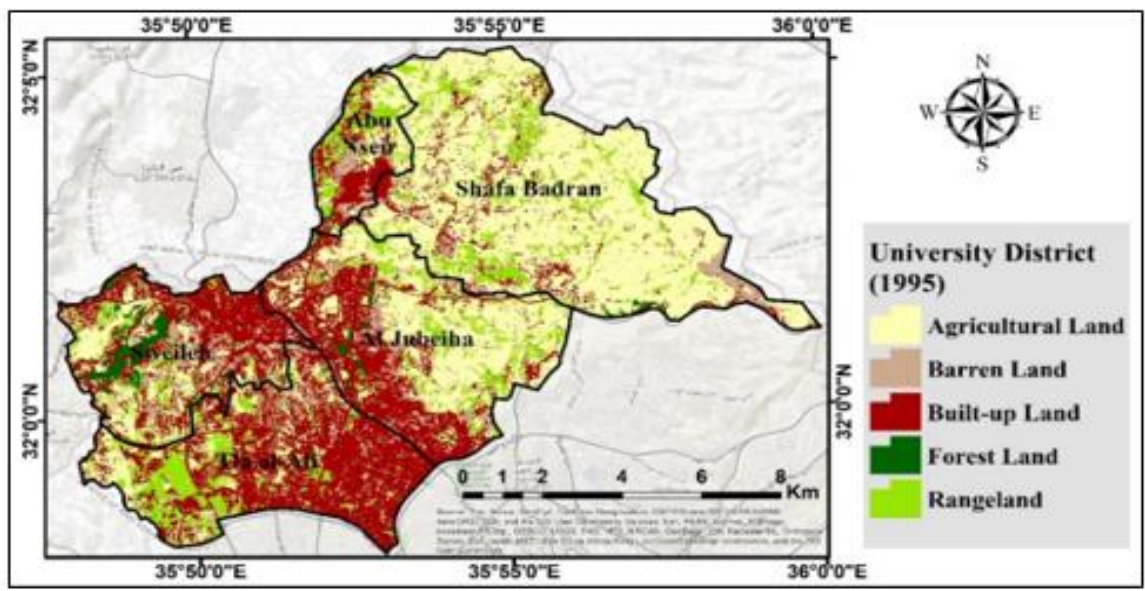

Fig. 5: Map of Land Use in The University District for The Year 1995. 


\author{
E-ISSN: 2469-6501 \\ VOL: 7, ISSUE: 9 \\ September/2021 \\ DOI: http://dx.doi.org/10.33642/ijbass.v7n9p1 \\ (c) (1) \\ https://creativecommons.org/licenses/by/4.0/
}

CPER

\section{-Change in Land Use for The University District During the Period Between 1995 And 2000.}

The Analysis of Figure (6) Shows the Change in Land Use in The University District, Where Urban Lands Increased by $14 \%$ Compared to 1995, And Barren Lands Increased by $19 \%$, And by Merge Forest Areas and Increasing the Ministry of Agriculture's Interest in The Region, The Forests Increased Agricultural-14\% Compared to 1995. So, The Agricultural Lands Formed (43694,556 Dunums) About 36\%, Urban Lands (43235,030 Dunums) By 36\%, Rangeland (20321.899 Dunums) With A Percentage of 17\%, Barren Land (10713.194 Dunums) 9\% Of the District's Area, And Forests (2975.999 Dunums) 2\% Of the Total Area.

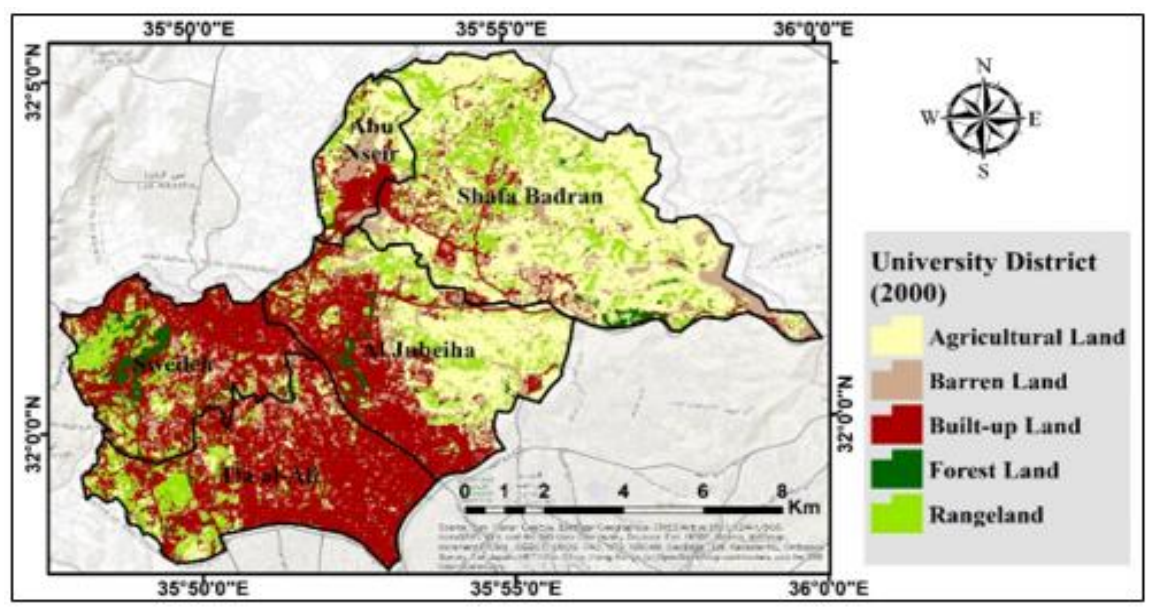

Fig.6: Map of Land Use in The University District for The Year 2000.

-Change in Land Use for The University District During the Period Between 2000 And 2005.

In This Stage, Emerges That the Urban Land Area Increases at The Against the Agricultural Lands as A Result of the Increase in Population Numbers. The Population for The Year 2004 In The District Reached $(279,359)$ People, While The Population in 1994 Was (166780) People, Meaning The Population Increased by an Annual Increase of $6.75 \%$, Which Is a Percentage Worthy of a Change in The Patterns of Land
Use in The District. The Change in Land Use Represented an Increase in Urban Areas by 29\%, A Decrease in Forests -26\%, Rangeland $-12 \%$, Barren $-32 \%$, And Agricultural $-13 \%$. Figure (7) Shows A Map of Land Use in The University District for The Year 2005. Urban Lands (55,547,881 Dunums) Formed $46 \%$, Which Is the Highest Percentage, Agricultural Lands (38,442,261 Dunums) 32\% Of The District's Area, Rangeland (17,681.119 Dunums) 14\%, Barren Lands (7,130,062 Dunums) By 6\%, And Forests (2,139,318 Dunums) Formed 2\%.

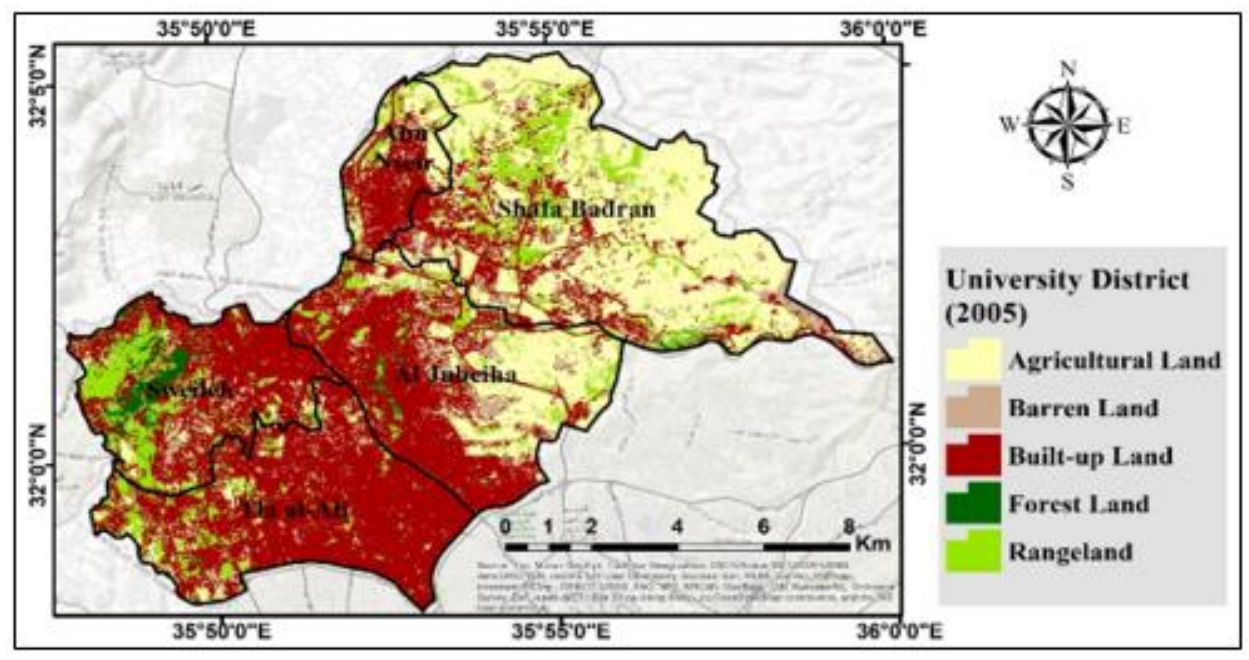

Fig.7: Map of Land Use in The University District for The Year 2000.

-Change in Land Use for The University District During the Period Between 2005 And 2010.

By Analyzing the Extent of the Change in Land Use for The Period 2005-2010, We Find That the Rangeland Increased by $22 \%$, Urban Use 10\%, Forests 9\%, Barren Lands Decreased 64\%, And Agricultural $-14 \%$. The Change Remained Fairly
Stable At This Stage, And There Were No Unnatural Factors Or Forced Migrations In The Region Until 2011 Ad, And Therefore The Area Of The Types Of Land Use Was Distributed With The Highest Percentage Of Urban Lands $(61,300,282$ Dunams) By 51\%, That Is, It Formed Half Of The Area, Which Is A Significant Increase From The Beginning Of 


\author{
E-ISSN: 2469-6501 \\ VOL: 7, ISSUE: 9 \\ September/2021 \\ DOI: http://dx.doi.org/10.33642/ijbass.v7n9p1 \\ (c) (9) \\ https://creativecommons.org/licenses/by/4.0/
}

The Study Period, Followed By Agricultural Lands Tendency To Graze Decreased To (2,335.729 Donums). That (33,102,132 Dunams) By 27\%, And We Notice A Continuing Is, about 18\% For The Year 2010 Ad, And Forests Remained Decline In Their Area Due To Urban Sprawl And Population (2,335,729 Dunams) 2\% Of The Area's Area, And The Barren Increase In The Region, As For Rangeland, They Differed Land Decreased to (2,570,974 Dunams) By 2\% Of The Total From Year To Year According To Weather Conditions Area of The District at This Stage. The Distribution of Them Is Represented By The Amount Of Rain And The Population's Shown in Figure (8).

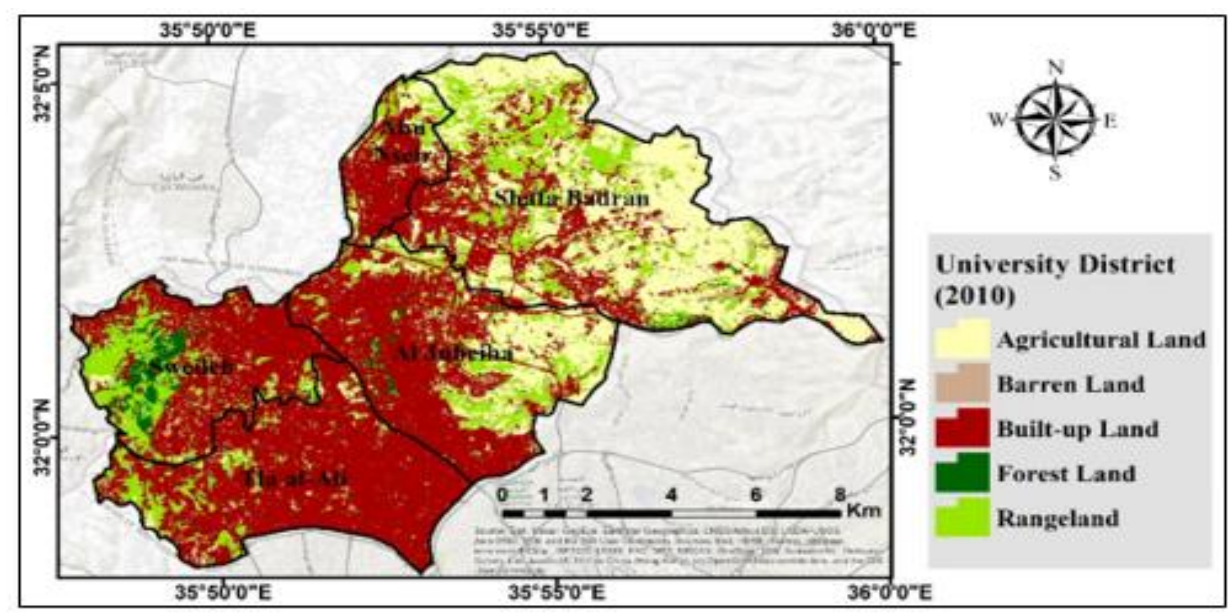

Fig. 8: map of land use in the university district for the year 2010.

-Change in land use for the university district during the period between 2010 and 2015.

This stage was marked by the influx of thousands of syrian refugees in 2011, the population of the district reached (743980 people) in the year 2015 , of whom (339202 people) $46 \%$ were non-jordanians). This increase, which amounted to approximately (15\% annually) by change rate of $(166 \%)$ resulted in to the expansion of housing, commercial and other projects during this period. Consequently, the region suffered from an $11 \%$ urban increase, and an increase in bare land by years.

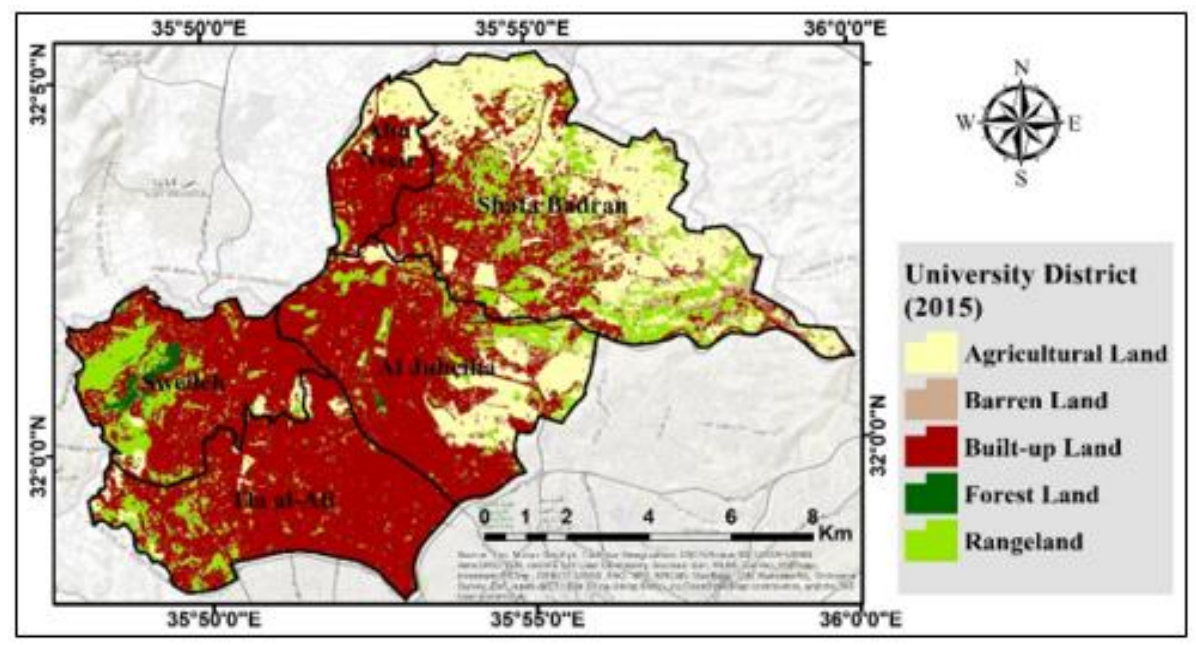

Fig.9: map of land use in the university district for the year 2015.

-Change in land use for the university district during the period between 2015 and 2019.

The region remained in a state of urban expansion during this period, and the population growth began to stabilize and the processes of migration to the district decreased, as the population reached ( 822540 people), thus land use changed with an increase in urban lands by $5 \%$ and https://ijbassnet.com/
$94 \%$, this increase was against of other varieties, which made agricultural use decrease by $-20 \%$, forests $-60 \%$, and rangeland $-4 \%$. Figure (9) shows the distribution of land use in the district for the year 2010 ad, the problem of urban lands $(67,652,091$ dunums) by $56 \%$ of the district's area, agricultural lands (26,608.459 dunums), or $22 \%$, and pastureland $(20,755,394$ dunums) by $17 \%$. As for barren lands, its area amounted to $(4,988,555$ dunams) by $4 \%$, and forests $(936,090$ dunums) at a rate of $1 \%$, i.e. retreating from what it was during the previous 


\author{
E-ISSN: 2469-6501 \\ VOL: 7, ISSUE: 9 \\ September/2021 \\ DOI: http://dx.doi.org/10.33642/ijbass.v7n9p1 \\ (c) () \\ https://creativecommons.org/licenses/by/4.0/
}

the year 2019, figure (10), we find that urban lands reached $(17,111.072$ dunums) and the barren $(4,136,429$ dunams) $3 \%$, (70,684,786 dunums) about $59 \%$ of the area of the university and forests $(1,328,291$ dunams), i.e. $1 \%$, as in the previous district, agricultural lands (27,679.952 dunums) by $23 \%$, and stage.

rangeland in the university district accounted for $14 \%$

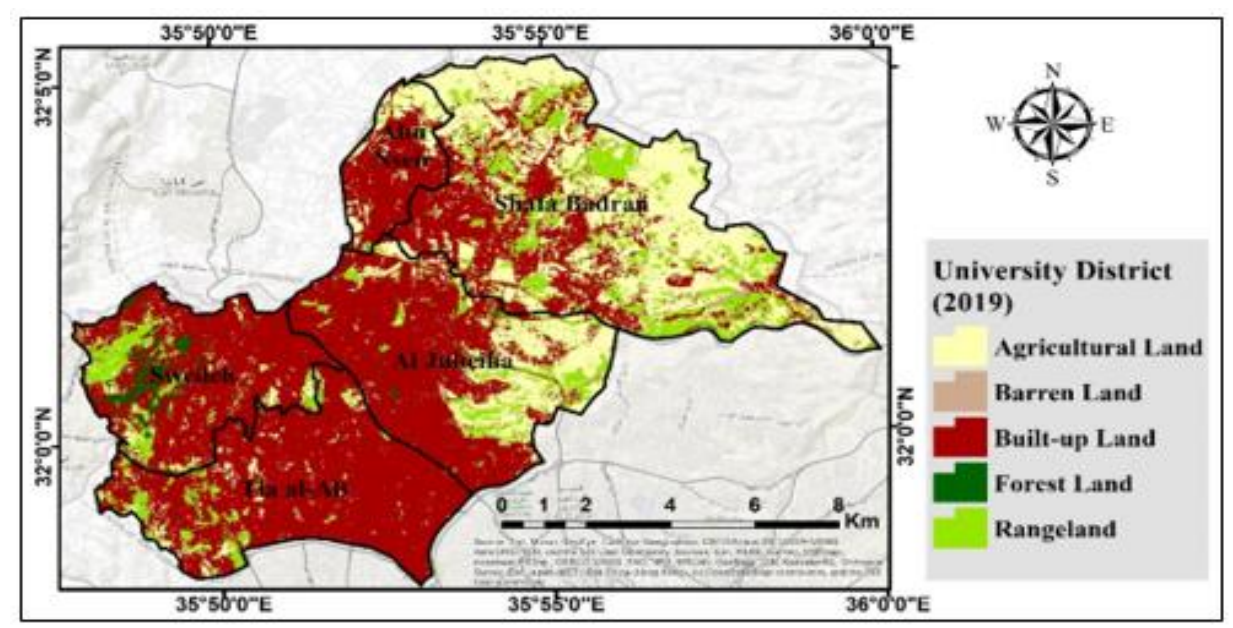

Fig. 10: map of land use in the university district for the year 2019.

Analyzing the extent of the change in land use in the university district for the period of study between 1985 and 2019.

Figure (11) shows that the university district exposed a change in the patterns of land use, by increasing urban areas at the expense of other types during the period (1985-2019), where the percentage of change in urban land area reached $125.5 \%$, and the rest of the classifications decreased, as follows: agricultural lands $(-40 \%)$, forests $(-50 \%)$, rangeland ($49 \%)$, and barren (-43\%), and as it was noted, the population was the main driver for the continuation of urban growth over the rest of the varieties, and by estimating the population at the beginning. The study period in 1985 ad $(55,890$ people), which became in 2019 ad (822540 people) in the district where a change was formed by (1372\%), which is an expected rate of change due to the length of the study period and the presence of exceptional factors that led to this increase and thus affected the urban lands to become (70,684,786 dunums) by $59 \%$ of the total area of the district in 2019 , after what was estimated at $(31,707.05$ donums), or about $26 \%$ of the total area in 1985; as it was noted from the land use maps for the region, the urban expansion was against of agricultural lands in a random manner, which was contributed by various factors, represented by the proximity of the area to the center of the capital and the presence of services in terms of transportation, infrastructure, and communications, while other varieties affected by urban growth decreased during the study period.

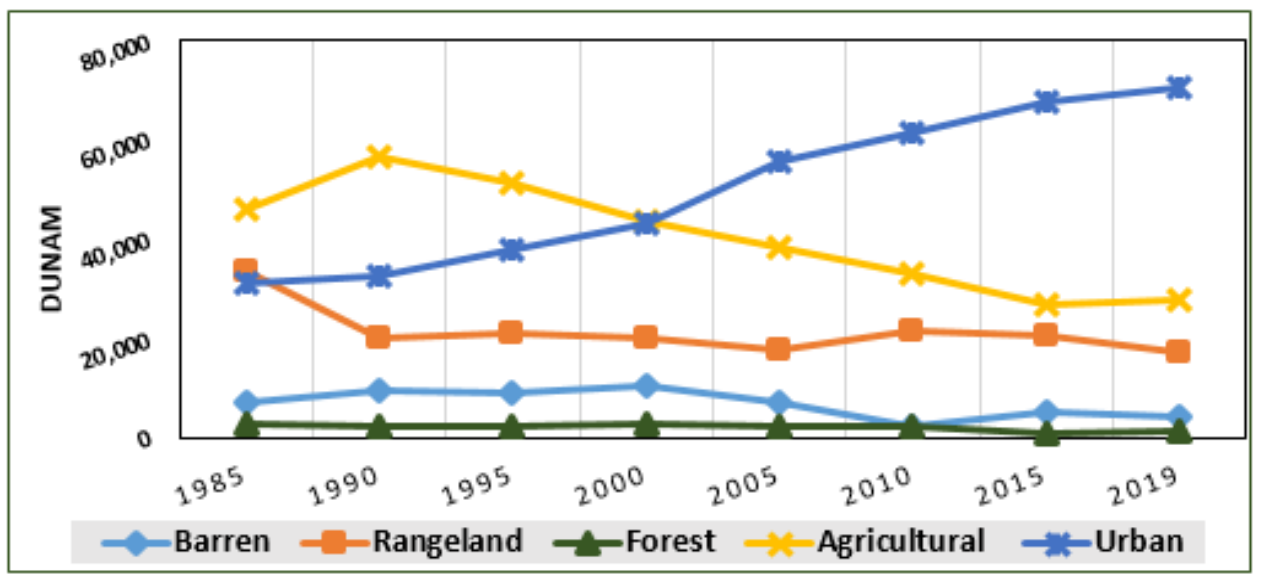

Fig.11: a diagram of the land use in the university district for the period (1985-2019), where the $\mathrm{x}$-axis represents the year in which the study was done, and the $\mathrm{y}$-axis represents the area of land use in dunums, and each figure represents a class of land use.

By analyzing the urban growth trend in the university growth to the boundaries of the urban area, as the urbanization district for the year 2019, and as shown in figure (12), we find has expanded to all areas of the district near the center of the that urbanization is $8,206 \mathrm{~km}$ to the north-east, $7,217 \mathrm{~km}$ to the capital amman, and the population growth has been affected by south-west, and 6,276 km to the west, from the center of urban tla 'a al-ali, jubaiha and sweileh, and abu nasir has the largest 


\author{
E-ISSN: 2469-6501 \\ VOL: 7, ISSUE: 9 \\ September/2021 \\ DOI: http://dx.doi.org/10.33642/ijbass.v7n9p1 \\ (c) () \\ https://creativecommons.org/licenses/by/4.0/
}

share of urban growth; due to its small geographical area and there is no sanitation facilities, in addition to the fact that compared to other areas of the district, and the least affected of the health care center only provider in the shafa badran area is them shafa badran, by referring to the services provided in the not equipped with emergency medical services and staff, and district's areas, we find that the shafa badran area lacks does not provide the residents of the area with the necessary transportation services, it is almost non-existent in some areas, health care.

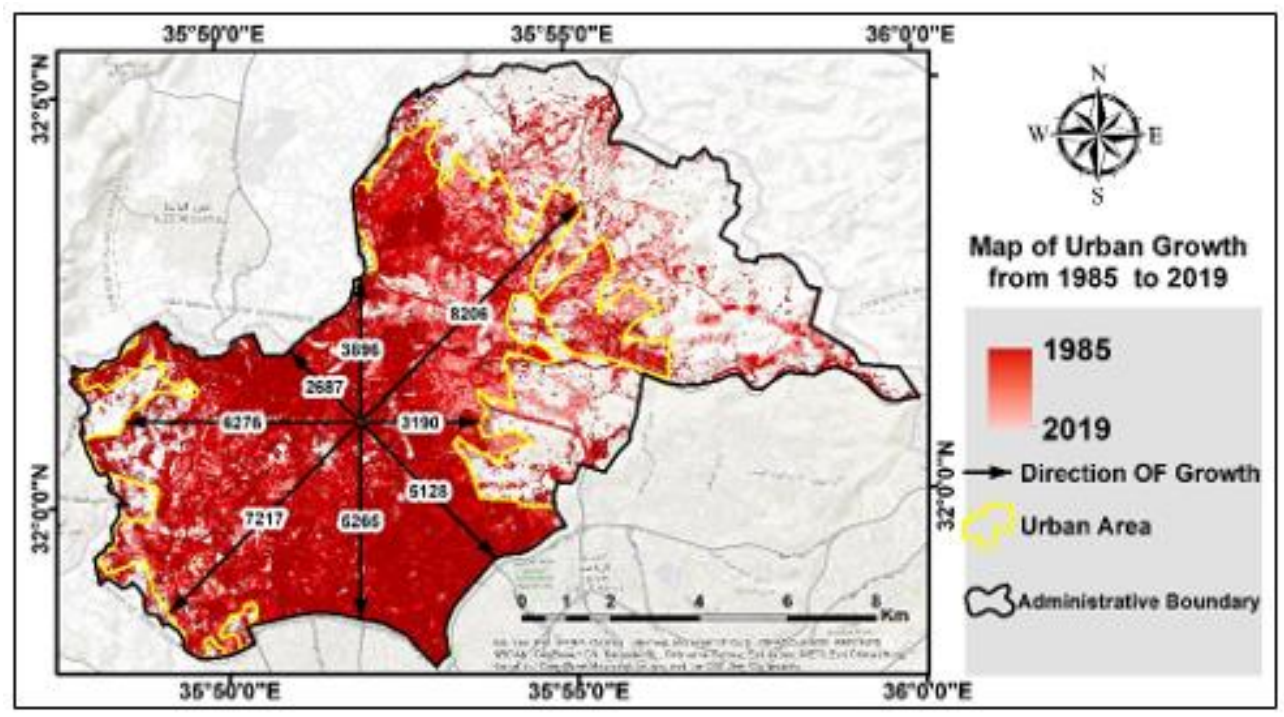

Fig. 12: urban growth trend in the jordan university district for the year 2019.

The future of agricultural and urban lands area in the Jordan university district.

Due to the importance of city planning, the urban and agricultural lands area was conceptualized for ten years following the study period through a prediction for the relationship of the population to changing land use patterns, and by using the logistic regression method, through which the relationship between the population and the urban and agricultural lands area in the study area was analyzed (luo et al. 2008), using Microsoft excel software to estimate the extent of the impact of the population in urban and agricultural lands during the period (1985-2019), then develop a mathematical relationship that represents this change; this resulted in figure (13), in which the values of the $\mathrm{x}$-axis (x) constitute the population in the district, while the values of the axis (y) constitute the area covered the urban or agricultural use in a dunum.

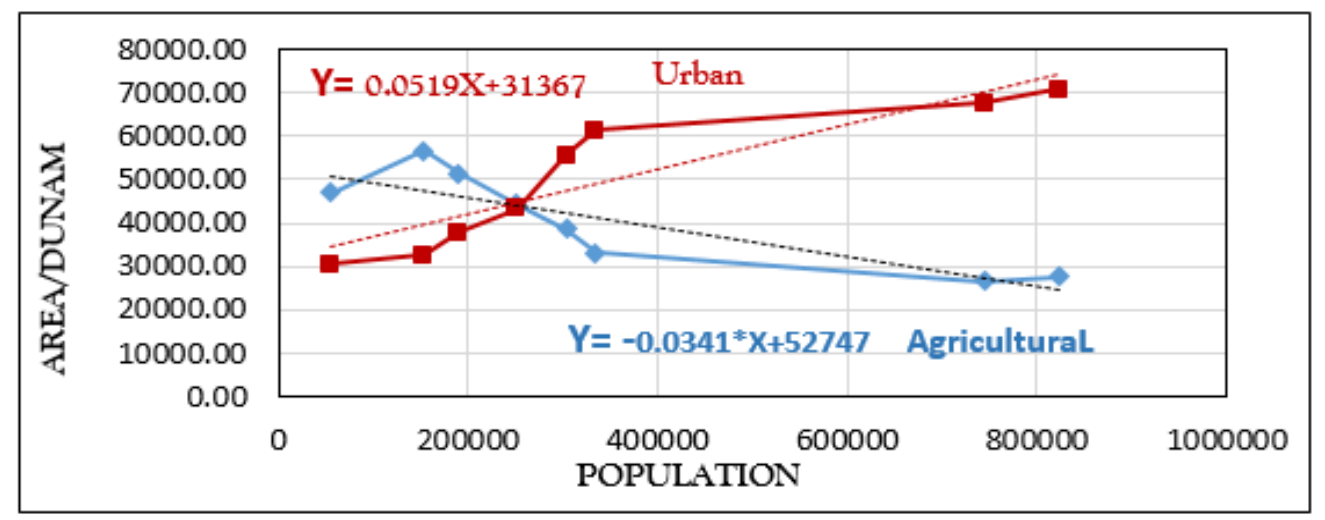

Fig. 13: the relationship of the population in both urban and agricultural lands 1985-2019, the x-axis represents the number of population and the $y$-axis represents the estimated area in dunums of both agricultural and urban lands.

As shown in table (2), which represents the expected change in the population and urban and agricultural land areas in the university district, by the year 2029 the district's population is expected to reach about (1587430 people), with an increase of (40\%) over the number of the expected population for the year 2020 , and this increase in the population was reflected in a relatively similar increase in the area of urban land, reaching about $(48 \%)$ over the area of urban utilized land for the year 2020 , in contrast, the area of agricultural land decreased in the face of an expansion in urban growth by (-9\%) annually, compared to its area for the year 2020, and this estimated change in the area of agricultural and urban lands would transform the area of the university's district into an urban area 
Table 2. Population and The Predicted Area of Agricultural and Urban Lands from 2020 To 2029

\begin{tabular}{cccc}
\hline YEAR & POPULATION & $\begin{array}{c}\text { AGRICULTURAL AREA } \\
\text { STATISTICS (DUNAM) }\end{array}$ & $\begin{array}{c}\text { URBAN AREA STATISTICS } \\
\text { (DUNAM) }\end{array}$ \\
2020 & 878437 & 22792 & 76958 \\
2021 & 938133 & 20757 & 80056 \\
2022 & 1001886 & 18583 & 83365 \\
2023 & 1069971 & 16261 & 86899 \\
2024 & 1142683 & 13782 & 90672 \\
2025 & 1220337 & 11134 & 92449 \\
2026 & 1303267 & 8306 & 96600 \\
2027 & 1391833 & 5285 & 101033 \\
2028 & 1486418 & 2060 & 105767 \\
2029 & 1587430 & --- & 110823 \\
\hline
\end{tabular}

\section{Conclusions}

1. This Study Presented Maps of Land Use in The Jordan University District During the Period 1985-2019, Demonstrates Through It the Patterns of Land Use and The Spatial Distribution of Urban, Agricultural, Barren Lands, Rangeland and Forests, Based On the Results of Analyzing Aerial Photos and Satellite Visuals for The Years (1985-1990-1995-2000-2005-2010-20152019).

2. The Difference In Spatial Distribution Ratios For The Types Of Land Use At The District Level For The Year 2019, Influenced By The Level Of Available Services, Population Growth Rates, The Difference In Average Land Values From One Region To Another, The Proximity Of The Area To The Center Of The Capital Amman, And The Area's Size; Therefore, The Highest Percentage Of Spatial Distribution Of Urban Lands Came In The District Areas For Tla'a Al-Ali 85\%, Followed By Sweileh 73\%, Then Abu Nasir $68 \%$, Then Jubeiha 65\% For The Year 2019, While In Shafa Badran The Largest Percentage Of Its Area Was In Favor Of Agricultural Lands, $43 \%$ Of The Same Year.

3. The Results of the Analysis of Land Use Maps in The District During the Study Period (1985-2019) Showed an Increase in The Urban Land Area by $125.5 \%$ And A Decrease in The Area of Agricultural Land by ($41 \%)$, And A Decrease in The Areas of Pastoral, Bare, And Forests by Proportions, (-49\%), (-42.6\%), ($50.5 \%$ ) respectively.

4. Population Growth Played a Significant Role in Changing the Patterns of Land Use in The Jordan University District, Especially During the Period 2010-2019, Due to The Involuntary Migration Represented by The Influx of a Large Number of Syrians from Outside Jordan into It, And The
Continued Rush of Population Numbers from The Northern Governorates to The Capital Amman and from There to The Brigade. The University.

5. The Results of the Analysis of the Urban Growth Trend Map in The Jordan University District Showed That Growth Is Heading North and North-East in Jubaiha, Tla'a Al-Ali, Sweileh, And Abu Nasir, affected by The Availability of Transport, Communication and Sanitation Services, While The Share of Shafa Badran Was the Least in The Urbanization Trend Towards These Areas Due to Poor Services Especially Sanitation Services.

6. By Anticipating the Area of Urban and Agricultural Lands, It Was Found That, With Continuous Natural Population Increase, The Encroachment of Urban Lands Against the Used and Unused Agricultural Lands, Which Shows the Transformation of the District into an Urban Land by The Year 2029.

7. The Results of Using a Simple Linear Regression Model to Predict the Future of Urban and Agricultural Land Areas in The District Showed That If the District's Population Growth Rates Remained at The Same Pace During the Period (2010-2019), The Area of Agricultural Land Will Become Zero by The Year 2029 In Favor of Urban Lands.

8. Creating an Interactive Web Map, Available to Internet Users of Land Use Patterns in The Jordan University District for The Period 1985-2019, Which Can Be Viewed Through the Link (Https://Arcg.Is/0hqgux)

\section{Acknowledgments}

I'm Pleased to Thank Those Who Advised Me, Guide Me, Directed Me, Or Contribute to Me in This Study, By Giving Me the References and Required Sources at Any Stage, Allow Me to Thank in Particular My Professors at Mut'ah University, Also I Appreciate Government Departments and Institutions in Jordan for Their Cooperation in Presenting the Various Data. 


\title{
International Journal of Business and Applied Social Science (IJBASS)
}

\author{
E-ISSN: 2469-6501 \\ VOL: 7, ISSUE: 9 \\ September/2021 \\ DOI: http://dx.doi.org/10.33642/ijbass.v7n9p1 \\ (c) (7) \\ https://creativecommons.org/licenses/by/4.0/
}

\section{References}

Al-Tal, Raed Salem, And Hala Hesham Ahmad Ghanem. 2019. "Impact Of The Syrian Crisis On The Socio-Spatial Transformation Of Eastern Amman, Jordan." Frontiers Of Architectural Research 8(4):591-603.

Doi: 10.1016/J.Foar.2019.06.003.

Anderson, James R. 1971. "Land-Use Classification Schemes-Used In Selected Recent Geographic Applications Of Remote Sensing." Photogrammetric Engineering 37(4):379-87.

Alsaleh, Mohammed (2010) "Processing Of Digital Remote Sensing Images Using The Ilwis Software” 1st Ed. King Saud University, Riyadh.

Alawran, Ali (2018) “The Use Of Geographic Information Systems And Remote Sensing Applications In Detecting The Impact Of Urban Expansion In Al-Eis City / Tafila Governorate On The Change In Land Use During The Period (1979-2015)

"Mu'tah University Jordan, Master Thesis.

Bennett, K. D., And R. W. Humphry. 1995. "Analysis Of Late-Glacial And Holocene Rates Of Vegetational Change At Two Sites In The British Isles.” Review Of Palaeobotany And Palynology 85(3-4):263-87.

Doi: 10.1016/0034-6667(94)00132-4.

Cao, Yu, Xiaoling Zhang, Yang Fu, Zhangwei Lu, And Xiaoqiang Shen. 2020. "Urban Spatial Growth Modeling Using Logistic Regression And Cellular Automata: A Case Study Of Hangzhou.” Ecological Indicators 113:106200.

Doi: 10.1016/J.Ecolind.2020.106200.

Department Of Statistics, Population Statistics, 2019, 2015, 2004, 1994, And 1979.

Esmail, Mohammed, Ali Masria, And Abdelazim Negm. 2016. "Monitoring Land Use/Land Cover Changes Around Damietta Promontory, Egypt, Using Rs/Gis.” Procedia Engineering 154:936-42. Doi: 10.1016/J.Proeng.2016.07.515.

Henry S. Shryock. 1976. The Methods And Materials Of Demography. Elsevier.

James R. Anderson, Ernest E. Hardy, John T. Roach, And Richard E. Witmer. 1976. A Land Use And Land Cover Classification System For Use With Remote Sensor Data.

Keshtkar, Hamidreza, Winfried Voigt, And Esmaeil Alizadeh. 2017. "Land-Cover Classification And Analysis Of Change Using Machine-Learning Classifiers And Multi-Temporal Remote Sensing Imagery." Arabian Journal Of Geosciences 10(6). Doi: 10.1007/S12517-017-2899-Y.

Lagarde, David, And Anne Bouhali. 2013. “Atlas Of Jordan.” Atlas Of Jordan (January 2014). Doi: 10.4000/Books.Ifpo.4560.

Luo, Jun, Danlin Yu, And Miao Xin. 2008. "Modeling Urban Growth Using Gis And Remote Sensing." Giscience And Remote Sensing 45(4):426-42. Doi: 10.2747/1548-1603.45.4.426.

Matouq, Mohammed, Tayel El-Hasan, Hussam Al-Bilbisi, Monther Abdelhadi, Muna Hindiyeh, Saeid Eslamian, And Salman Duheisat. 2013. "The Climate Change Implication On Jordan: A Case Study Using Gis And Artificial Neural Networks For Weather Forecasting.” Journal Of Taibah University For Science 7(2):44-55. Doi: 10.1016/J.Jtusci.2013.04.001.

Matsa, Mark, Oshneck Mupepi, Tatenda Musasa, And Rameck Defe. 2020. "A GIS And Remote Sensing Aided Assessment Of Land Use/Cover Changes In Resettlement Areas; A Case Of Ward 32 Of Mazowe District, Zimbabwe.” Journal Of Environmental Management 276:111312. Doi: 10.1016/J.Jenvman.2020.111312.

Ministry Of Agriculture, Soil Map, The Jordan University District, 2012.

Ministry Of Water And Irrigation, Weather Forecast, Annual Rate Of Evaporation, 2012.

Ministry Of Water And Irrigation, Average Annual Rainfall, 1990- 2019.

Namboodiri, N. Krishnan, Henry S. Shryock, And Jacob S. Siegel. 1973. “The Methods And Materials Of Demography." Social Forces 52(1):129. Doi: 10.2307/2576436.

Park, Soyoung, Seongwoo Jeon, Shinyup Kim, And Chuluong Choi. 2011. "Prediction And Comparison Of Urban Growth By Land Suitability Index Mapping Using Gis And Rs In South Korea." Landscape And Urban Planning 99(2):104-14. Doi: 10.1016/J.Landurbplan.2010.09.001.

Potter, Robert B., Khadija Darmame, Nasim Barham, And Stephen Nortcliff. 2009. “Ever-Growing Amman', Jordan: Urban Expansion, Social Polarisation And Contemporary Urban Planning Issues.” Habitat International 33(1):81-92.

Doi: 10.1016/J.Habitatint.2008.05.005.

Ramachandran, S., R. Krishnamoorthy, S. Sundramoorthy, Z. F. Parviz, A. Kalyanamuthiah, And K. Dharanirajan. 1997. "Management Of Coastal Environments In Tamilnadu And Andaman \& Nicobar Islands Based On Remote Sensing And Gis Approach. Maeer's Mit." Pune Journal, Iv (15 \& 16), Special Issue On Coastal Environmental Management 129. 
The Royal Jordanian Geographical Center, Topographic Maps, Al-Jubeiha Tablet, 1:50000, Volume 2, 2010.

The Royal Jordanian Geographical Center, Map Of The Administrative Divisions Of The Hashemite Kingdom Of Jordan, 2009. Schaefer, Mathias, And Nguyen Xuan Thinh. 2019. "Evaluation Of Land Cover Change And Agricultural Protection Sites: A Gis And Remote Sensing Approach For Ho Chi Minh City, Vietnam.” Heliyon 5(5):E01773.

Doi: 10.1016/J.Heliyon. 2019.E01773.

Zreqat, Dala .2016. "Land Cover Change And Land Use In Azraq District / Zarqa Governorate In The Period 1978-2015 Using Geographic Information Systems And Remote Sensing” Jordan Journal Of Social Sciences, Volume 9, Issue 3, University Of Jordan, Jordan.

Https://Earthexplorer.Usgs.Gov/

Www.Arcgis.Com/Index.Html

Https://Www.Arcgis.Com 